\title{
Luis Banchero Rossi (1955-1972), the best entrepreneur in Peru's fishmeal industry: market governance, social capital, and embeddedness
}

\begin{abstract}
In the 20th century, Peru was one of the major fishmeal producers worldwide. Luis Banchero Rossi (1929-1972) was the main driving force behind this economic boom. This article discusses how, given a set of historical conditions favoring such a setting, Banchero's business performance surpassed that of other Peruvian and foreign producers in the industry, and enabled this development. This research uses complementary methodologies; i.e., case study work and financial databases. The authors find that Banchero's share in Peru's total exports reached $15.3 \%$ in 1968, far above the next largest Peruvian exporter. In this regard, Banchero operated his organization following a set of criteria, called market governance by Williamson, plus several advantages, including negotiation abilities, social capital formation, human capital management, and tacit knowledge development, building on Peru's specific sociological conditions. These conclusions help understanding how an entrepreneur of humble origins like Banchero worked around a commodity such as fishmeal to become a successful business leader worldwide.
\end{abstract}

Keywords: Luis Banchero Rossi; social capital; fishmeal; market governance; transaction costs; tacit knowledge

Corresponding author: e-mail: @ub.edu

Received October 7, 2020 - Accepted March 1, 2021

This is an Open Access article distributed under the terms of the Creative Commons Attribution-Non-Commercial-No Derivatives License (http://creativecommons.org/licenses/by-nc-nd/4.0/), which permits non-comercial re-use and distribution, provided the original work is properly cited, and is not altered or transformed in any way. 
A man's character is his fate.

Heraclitus

\section{Introduction}

Peru has been a leading fishmeal producer since the beginning of the 1950s. Production grew 119 times in 1954-1971 (Seminario 2015); and the average annual export volume increased from USD 0.8 million in 1950-54 to USD 188 million in 1970-73. Fishery exports surged from $2.9 \%$ to $27.0 \%$ of total exports in 1960-67 (Thorp and Bertram 2013). Peru's fishery boom was sparked by a critical set of historical and structural conditions: natural anchoveta abundance created by the Humboldt Current; high economic momentum in 1943-1976, on the back of demographic expansion, tertiary industry development, and mining growth; and the emergence of scores of risk-taking, innovative Peruvian and foreign fishing entrepreneurs.

In this context, as a result of a spectacular industrial onslaught, by 1968 Luis Damiano Manuel Banchero Rossi produced $15.3 \%$ of total fishmeal exports, 2.6 times ahead of his closest Peruvian competitor (Abramovich 1973).

How did this son of Italian immigrants, with no family background in the business, scarce initial capital, studies in a provincial university, and no English literacy become such a success story? How did this newcomer who did not begin to invest in fisheries until 1950 and was initially snubbed by the business community (whose arrogance he bitterly criticized) build one of Peru's largest fortunes? (Malpica 1992). It has to do with the identification and implementation of innovations - using nylon instead of cotton nets, echo sounders to locate fish, and helicoidal impeller centrifugal pumps to transport catch from ship to plant—but also crucially with a creative use of tacit knowledge, social capital, and personal qualities. 
This paper explains how Banchero's historical and personal circumstances contributed to his achievements by using various methodological approaches (mainly the case study method, as well as close research of his life and times) and sources (the Economática corporate database system); and the Peruvian journal Pesca.

\section{Fisheries in Peru: economic and political developments (1959-1975)}

Peru experienced an economic boom in 1943-1976, with an annual average growth of $5.13 \%$ (Seminario 2015). At the same time, fiscal deficits remained high (above 10\% of GDP in 1968); the foreign debt increased considerably to finance public works; and annual inflation exceeded two digits in 1957 (12.7\%), 1965 (16.3\%), and 1968 (19.2\%). Moreover, in 1959-1975, six presidents came to power. One of them, Juan Velasco Alvarado, nationalized fishing companies.

FigURE 1. Fishmeal statistics

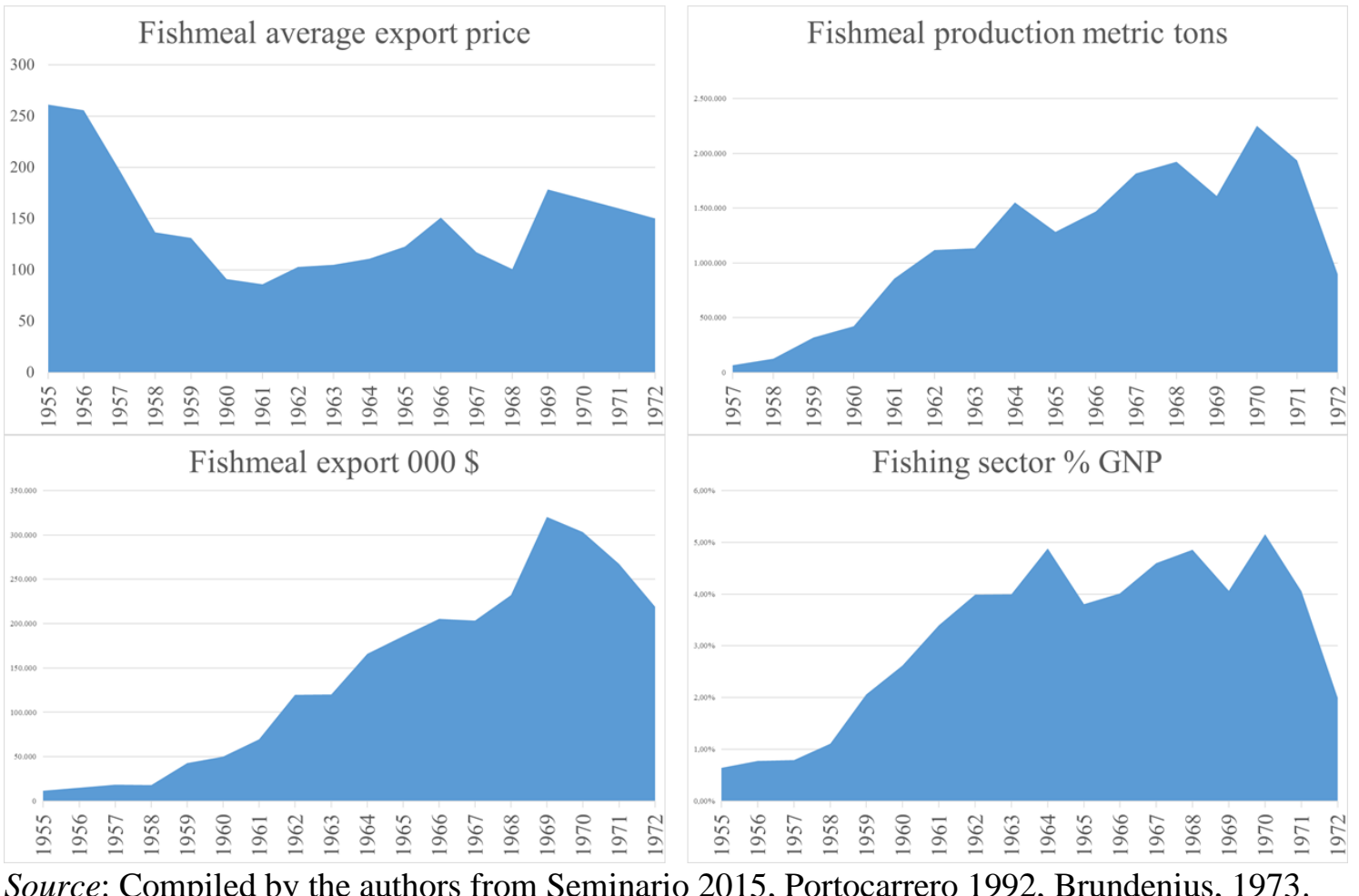


A major driver of this economic momentum was fishmeal production, which gained importance in international markets as livestock feed and offset the fall of other commodities-like bird manure fertilizer (guano) —within Peru's commodity exports.

In 1955-1972, fishmeal prices fluctuated between a high of USD 261/ton and a low of USD 86/ton, with a standard deviation of USD 51/ton (Figure 1). Along with Angola, Norway, South Africa, the U.S., Denmark, Spain, Iceland, and Portugal, in 1960 Peru joined the Fishmeal Exporters' Organization (FEO), which promoted strategies to hedge against market volatility. In the same year, the industry's main stakeholders founded Peru's Fishing Consortium (Consorcio Pesquero del Perú) to organize fishmeal exports, fight speculation, and establish a distribution system. Up to $92.5 \%$ of fishmeal production was controlled by the Consortium (Thorndike 2019).

Fishmeal production almost doubled yearly in 1955-1960 and reached a historical high of 2,249.247 tons in 1970 (5.16\% of GDP, compared with less than 0.5\% in 1955). Exports surged to a peak in 1969 (36\% of total exports). During this period, Luis Banchero Rossi became a main figure behind the fishmeal boom and reputedly built one of Peru's largest fortunes. The next sections suggest that this claim may be overstated.

\section{Banchero Rossi: entrepreneur, innovator, and strategist}

Luis Banchero Rossi was born on October 11, 1929 in Tacna (Peru). His parents, both immigrants from the village of Carsi (Italy), ran a vineyard and a wine-and-pisco mill. He had a brother and two sisters. When he graduated from high school, he left the parental home due to differences with his father. He settled in the city of Trujillo, where his uncle Benito Rossi Sattui-his mother's brother, also an immigrant-encouraged him to study chemical 
engineering at the local university. Graduation remained an unfulfilled goal that stalked him throughout his life despite his business success, until he finally obtained his degree much later, at 42, just two months before his untimely death in 1971 (Rossi 2011, 15-16).

A born businessman, he started out selling soap as a college student. On one occasion, his cousin Mario Rossi, Benito Rossi Sattui's son, also a chemical engineering student, set out to make soap, which had become temporarily scarce in the market. He judged his experiment a failure, but Luis took the soap and succeeded in selling it. He then asked Mario and his classmates to make more despite their material limitations and rudimentary production techniques (Thorndike 1980, 56-57).

Having completed his studies at the age of 21 in 1951, he embarked in several business ventures with his cousin Alicia Rossi de la Riva, Benito Rossi Sattui's daughter. While selling Kendall tractors and lubricants in Peru's northern estates, he befriended Yugoslavian immigrant Radovan Samardzic, also a lubricant seller. Further pursuing business opportunities, he began selling liquor, including at the important Laredo plantation, where he became acquainted with engineer Isidoro Loebl. He realized that molasses (a by-product of sugar refining) could serve as livestock feed. Banchero took the risk: "I'll buy all the waste" (Thorndike 1980, 68; Rossi 2011, 16). When his bid proved successful, he founded the Productos y Forrajes company. He also became lubricant supplier to a fish canning plant located in the fishing locality of Coishco, near the city of Chimbote, where his cousin Mario Rossi, now a chemical engineer, was in charge of quality control. In Chimbote he developed a close partnership with Galician immigrants Fernando and Luis Pazos Caeiro, who introduced him to the vast potential of Peru's fishing industry (Rossi 2011, 16). 
Banchero also befriended Juan Sagarvarría, a chemical engineer of Basque and Italian descent. Sagarvarría worked with his brother in law, who owned the Envasadora Chimbote company; and also willingly shared his experience in fisheries with Banchero. Shortly afterwards, in 1955, Banchero decided to make a push into the nascent fish canning industry by creating Compañía Pesquera La Florida S.A. He bought an inoperative plant subject to seizure for debt and took its assets to Chimbote, where operations began in October 1955 with logistical assistance from Samardzic, "always the right friend at the right time" (Rossi 2011, 17). He also succeeded in engaging Carlos A. Mannucci (a Trujillo businessman of Italian descent) and Ignacio de la Riva (married to his cousin Alicia Rossi) in the venture.

In 1955 fishery industries were incipient, consisting mainly of bonito canning for export, but also anchoveta fishmeal, pioneered by Manuel Elguera McParlin, Miguel Capurro and other entrepreneurs like Manuel Almenara. In 1945 the latter founded the Chimbote-based Compañía Pesquera Coishco, to which Banchero was originally a supplier of motor lubricants (Cushman 2018, 431). Chimbote was thus gradually becoming a fishing center led by entrepreneurs of Italian and Galician descent, the latter mostly from the Spanish fishing port of Malpica (Rossi 2011, 21). Soon, for logistical and other reasons, Banchero Rossi opened an office in Lima, located in a space provided by the manager of the lubricant company for which he used to work. Banchero Rossi, then 26, commuted weekly between Lima and Chimbote. Benito Rossi, his future biographer, was 21 when he enrolled in the new company (Rossi 2011).

Bonito canning and anchoveta fishmeal plants mushroomed along coastal Peru throughout the 1950s, including U.S. company Star Kist, which formed partnerships with Almenara and with the plants located in Coishco and the southern port of Ilo. The industry's precarious conditions initially limited Banchero's efforts to venture into bonito fishing: he depended on widely 
fluctuating prices set by shipping vessel owners, as well as on their wooden ships (bolicheras) with no more than a 60-ton hold capacity. He then launched a 40-ton fishing vessel in November 1956; and commissioned five more with the same hold capacity in 1957, as well as thirty-one 120-ton ships in 1960. Previously, in 1959, Banchero had already made a daring move by commissioning the 130-ton ship "Tacna", the first steel fishing vessel, followed by five more with the same hold capacity (Rossi 2011, 53). The latter could also serve as factory ships; but there were concerns about their ability to float and the corrosion of steel in seawater. The experienced Pazos Caeiro brothers came up with the solution: using galvanic current to weld ship parts.

Banchero's initiatives illustrate the push to overcome the industry's incipient know-how and lack of technical sophistication in shipbuilding, fishing practices, transportation, and methods for unloading from fishing vessels to canning and fishmeal processing factories. Crucially, the process also involved identifying international market opportunities, disclosing Peru's rich fishing potential, and investing exiguous capital in a timely and risk-savvy manner.

Fishmeal was initially produced using bonito waste, but later there was a massive shift towards anchoveta promoted by Banchero and others. The year 1958 marked the beginning of the international fishmeal boom (as well as the decline of bonito fishing and a surge in South African demand for canned sardine and mackerel). Using facilities purchased from Californian investors at bargain prices, Banchero established a plant in Chimbote with a production capacity of 20 tons per hour, in partnership with US company Wilbur Ellis and Peru's Compañía Industrial Pesquera del Pacífico Sur S.A. Taking advantage of a price fall, Banchero offered to buy Wilbur Ellis's share in kind; changed the company's name to Pesquera Humboldt S.A.; and named former classmate Alfonso Puga López as plant manager, as well as other college friends 
(Rossi 2011, 16, 32). He also hired his brother-in-law, Orlando Cerrutti, a police captain, to run the operative and administrative areas. Rossi emphasizes that Banchero "[...] needed to appoint only men he could fully trust in places of responsibility." (Rossi 2011, 32). At the same time, he closed down his molasses and tannery activities due to low turnover.

After establishing fishmeal companies Pesquera Humboldt S.A. in Chimbote, Pesca Mar S.A. in Supe, and Los Ferroles S.A. in Callao, as well as canning plants La Florida S.A. and Miramar S.A. separately for tax purposes, OYSSA (Operaciones y Servicios S.A.) was created to coordinate operations and expansion plans for the Group as a whole.

Mounting foreign demand had to be met by stepping up production, but within a framework of lean management, efficient logistics, daring innovation, and continuous learning. These materialized in a vertical integration arrangement involving a fleet and a shipyard of adequate size. Banchero had to develop sound decision-making and capacity building practices on the spot, as universities and other education institutions did not offer careers in shipbuilding, fisheries, or plant design. Initially Banchero's brother-in-law, civil engineer Enrique Agois, was appointed as OYSSA general manager; but remained in that position only until 1962, as his conservative approach clashed with Banchero's bold methods (Thorndike 1980, 48). As part of his plans to revamp financial and cost management practices, Banchero hired engineer Isidoro Loebl, former supervisor at Azucarera San Jacinto, whom he had met while doing business in northern Peru.

Banchero's logistical strategy included a comprehensive information system encompassing the accounting and operative areas. The efficiency gains from this approach resulted from coordinating costs and capacity in all the Group's plants and vessels (approximately 200 ships, 
3,000 fishermen, and administrative staff). The fleet needed to be equipped with radios, echo sounders, sonars, pumps, power blocks, etc. In 1959-60 nylon nets replaced cotton nets. Soon it also became necessary to establish a shipyard (Pesquera Industrial Callao S.A., PICSA) to build the Group's own vessels, as well as a dry dock (Astilleros Chimbote S.A) for maintenance and repair (Rossi 2011, 59, 73).

Fishmeal production costs were initially low: the cost was USD 50/ton, and the selling price could reach USD 150/ton (Thorndike 1980, 166); but price volatility and speculation remained serious drawbacks. In 1959, Peruvian producers confronted Comergal, a powerful international fishmeal trader owned by Spanish national Joaquín Peña. In addition to fishmeal produced in Angola, Peña speculated with Peruvian fishmeal supplied by a local company. He even visited Peru and offered Comergal's trading services to fend off competition and secure a minimum price per ton, but negotiations failed (Thorndike 1980, 167, 168, 170-174). Around that time, the FEO was created in the context of the Paris Agreement (October 1, 1960) on the basis of the international market regulatory framework issued by the International Association of Fishmeal Manufacturers (IAFMM). Peru's National Fisheries Association (Sociedad Nacional de Pesquería) adhered to the agreement; and shortly afterwards, on November 21, 1960, Peru's Fishing Consortium was established, on Banchero's initiative, to combat speculation, provide technical assistance, and ensure contract compliance. Peña's speculation scheme consisted of selling in advance at a price below fishmeal production costs to break competition from Peru. After a 44-day standoff, with prices already on the rise, the Peruvian Consortium delivered 30 thousand tons of fishmeal into the market at USD 115.00 FOB. Moreover, Banchero had previously carried out massive purchases of Comergal fishmeal from third parties at low prices. 
Market participants began to purchase from the Consortium, marking a victory in the trade war against Peña (Thorndike 1980, 184, 185, 187-189).

The Banchero Group implemented organizational improvements continuously. In 1965, the Fleet Manager's Office was created and placed under the General Manager's Office, together with the Production Manager's Office. The Fleet Manager's Office comprised the Operations, Maintenance, and Finance Departments, as well as the Research Unit. The Operations Department supervised the fleet chiefs and plant superintendents. The Maintenance Department team comprised mechanical engineers, electricians, electronics engineers, and refrigeration specialists. The Finance Department was in charge of budget preparation and implementation. The Research Unit followed up on world production statistics. Humboldt International, the Group's maritime transport company, managed ships with a 10-ton hold capacity (Rossi 2011, 60, 69). The OYSSA fleet grew to 191 ships: 145 anchoveta vessels, 18 bonito vessels, 21 trawlers, 4 tuna vessels, and 3 auxiliary vessels (Rossi 2011, 79). As a consequence of this extraordinary expansion, in less than ten years Peru became the world's leading fishmeal producer. Banchero was also keen to promote capacity building among his employees, for instance via the workshop for fishing vessel skippers, created in 1964 (Rossi 2011, 99).

In 1966, the enactment of an export tax affected operations and provoked a strike. In addition, different sources indicated that the largest companies in the fishing consortium were responsible for ecological imbalances: the mass death of guaneras birds (Caravedo 1979). Moreover, the government declared a closed season for fishing in 1967. A political solution was found: Congress approved an income tax on profits and a reinvestment incentive. This reflected Banchero's increasing influence on politics. In fact, by the end of the 1960 s there was speculation that Banchero might run for president. However, on October 3, 1968, in a context 
of political crisis, government corruption allegations in the media, hostile relations between Congress and the Presidency, and social unrest, General Juan Velasco Alvarado staged a coup and established a left-wing statist government. The relations between the regime and Banchero became increasingly strained. Banchero's life came to an abrupt and violent end on January 1, 1972. The reasons behind his assassination, which provoked widespread repudiation, remain undisclosed to this day. His extraordinary rise to success and his sudden death raised him to legendary status. His reputation as an austere, indefatigable man set him apart from the traditional upper crust; and earned him an almost prophetic and providential quality in the popular mind.

\section{The Banchero fortune}

How large was Luis Banchero's fortune? Was he Peru's richest man by the beginning of the 1970s? His investment portfolio has been valuated and compared with other Peruvian fortunes of the time to answer this question.

Although it is difficult to obtain the necessary data in a country with a rather shallow capital market like Peru, relevant information was obtained from the institutions and publications mentioned in the introduction to this paper. In Figure 2, companies marked with an asterisk (*) are associated with fisheries (production or commercialization) and operate under a vertical integration arrangement; i.e., inputs are purchased from their own suppliers and sold as transformed goods to firms also within the same Group. The only exception is the firm at the end of the production chain; i.e., the one that makes the final sale.

All intermediate goods and services (fish, fishing vessels, nets, etc.) served to produce the exports made by Hamburg-based Humboldt International. For example, all ships built by 
PICSA served only to export the Group's fishmeal and canned fish. Although PICSA did sign contracts to sell five ships to French firm Pretabail, sixteen 600-ton vessels to Cuba, and five ships to Peruvian firm Pepesca, the 1973 nationalization prevented their delivery (Rossi 2011, 125). These sales to third parties, which could have increased the worth of Banchero's portfolio, never materialized.

TABLE 1. Banchero's portfolio valuation

\begin{tabular}{|l|c|c|}
\hline Banchero's Portfolio (1968) & \multicolumn{2}{|c|}{ USD thousands } \\
\hline Fishing & High & Low \\
\hline Fishmeal & 43,314 & 12,032 \\
\hline Canned fish & 11,832 & 3,287 \\
\hline Sub-total & 55,146 & 15,318 \\
\hline
\end{tabular}

Source: Compiled by the authors.

We assume that a company's equity (at market prices) can be estimated by multiplying an accounting indicator (sales) times a price sales ratio. The twin security chosen was Austral Group, a fishmeal exporter, with a 0.5-1.8 ratio. Banchero's fishery-related wealth (i.e., fishmeal and canning) in 1968 USD is estimated at USD 15-55 million (Table 1). The Banchero Group included other interests like the Correo newspaper, the Seguros Panamericana insurance company, and the Defensor Lima soccer team.

Although calculating Banchero's worth is a complex exercise, it is possible to arrive at reasonable conclusions. The fortunes of Peruvian economic groups ${ }^{1}$ Romero, Wiese, Bentín, and Brescia in 1968 USD are estimated at USD 108, 101, 32, and 31 million, respectively. It should be noted that the latter are based on 1995 information from the Lima Stock Exchange, which does not include important unlisted companies. Clearly, the Romero and Wiese fortunes

\footnotetext{
${ }^{1}$ Only the share owned by the Group is considered.
} 
were more important, with far more diversified investments in strategic sectors like banking, chemicals, mining, and hotels (Vásquez 2000).

\section{The distinctive advantage of the Banchero Group: market governance, transaction cost, social capital and embeddedness}

As discussed in the previous section, Banchero's net worth was not one of Peru's major industrial fortunes. However, after starting operations in 1955, by 1968 Banchero had become Peru's first fishmeal producer, with a 15.3\% share of total exports (Abramovich 1973). The second was Proteins Corporation, a US company; and the third was Madueño \& Elguera, a Peruvian company (Roemer 1970), both well below Banchero's output. The remainder of this section discusses the question advanced in the introduction: how did Banchero's entrepreneurial performance surpassed that of all locally-based Peruvian- and foreign-owned companies and international corporations, starting from an exiguous capital, eventually becoming the largest producer in the world's main fishmeal exporting country?

The historical-structural circumstances favored the fishing industry as a whole, with entrepreneurs competing aggressively against each other. Therefore, in principle, the extraordinary growth of fishmeal production/exports over that period could have been basically the same without Banchero.

The value-added process for fishmeal is relatively simple and imitable. Like in the case of other Peruvian commodities (e.g., guano and nitrate in the 19th century, or mining at the turn of the 21 st century), fishmeal production surged in a favorable economic and geopolitical context of rising demand and prices. In line with international trade theory, Peru's fishmeal export boom relied on a basic endowment, a fish-rich maritime territory. Specifically, the Humboldt 
current — which also cuts through an important segment of Chile's territorial waters-creates rich nutrients for fish, notably anchoveta. Other factors include pseudo-scientific studies, the creation of the National Fisheries Association, and laws allowing anchoveta over-exploitation. By end-1953, ten fishmeal processing plants were already in operation (Cushman 2018, 428431).

Therefore, Peru probably enjoys an absolute advantage in fishmeal production. There are no relative costs, but Peruvian fishers face low opportunity costs. The world fishmeal market can be described as an oligopsony, where few buyers (like Wilber Ellis, Coishco, and FIPECO) compete to purchase a given good. (Thorndike 2019). In addition to the historical factors mentioned above, technological conditions were more or less accessible to all entrepreneurs in the industry, depending on their economic capital or financing capacity. Fishing innovations included nylon (instead of cotton) nets, the echo sounder (which facilitates fish catch), and helicoidal impeller centrifugal pumps (which facilitate unloading fish catch from ships to processing plants).

But why was a company like, for instance, Proteins Corporation - which had access to greater financial and managerial resources, operated under a fully integrated process, and was run by seasoned managers-unable to equal Banchero's achievements and impose its dominance by sheer "brute force" (i.e., taking over the market by exploiting economies of scale)? A first hypothesis is that Banchero created competitive advantage by establishing vertical and horizontal links within a group of companies, i.e., what Michael Porter calls a cluster (Porter 1991). This hypothesis assumes the ability to measure tangible resources and free trade. Moreover, development is explained by formal knowledge; that is, it can be expressed in words and numbers (cost-benefit analysis) and it is explainable (i.e., in can be expressed by a model). 
However, the limitation of this framework is that it does not consider intangible resources, which are also fundamental in this case.

So how did Banchero prevail over all other companies? How did he weather the successive crises that occurred during the 1960s? How did he compete against, and surpassed, all foreign and transnational corporations investing in Peru at that time? We suggest two concepts that can contribute to resolving this issue: transaction costs and market governance; and social capital and its embeddedness in Peruvian society.

The transaction costs approach focuses on governance costs and relegates production costs to a lower priority. The issue is establishing whether the compartments generated by production should transfer resources as independent units via purchases or outsourcing (market governance), or under the supervision of a higher layer of authority (unified governance), thereby promoting vertical integration. Both mechanisms create different governance costs. The problem is deciding who controls production, the market or the company. Market governance originates market costs: data gathering, negotiation between the parties involved, and insurance and transportation for purchasing and outsourcing. Alternatively, under unified governance, costs are generated when resources are mobilized under the owner's planning and direction. The difference between both approaches is the generation of transaction costs. A company will tend to grow until the cost per additional transaction within the company is equal to the cost of carrying out the same transaction via the market.

If all agents were loyal, products were homogeneous, and information was complete, both kinds of governance would originate the same cost. However, in most societies there is opportunism, products are heterogenous, and information is incomplete. Therefore, costs differ between both 
kinds of governance, but respond to three parameters: asset specificity, uncertainty, and frequency. On one hand, a less specific asset may be employed in different ways by different users without value loss, although, due to its simplicity, it will not generate significant benefits. On the other hand, a more specific asset cannot be used for alternative purposes, although it can take on a strategic behavior, thereby creating considerable gains. Uncertainty means that information is insufficient to protect an agent against fraud. Frequency refers to the number of transactions. Market governance implies equality of power between the negotiating parts, as well as anonymity. Costs are lower than under unified governance when products and technologies are simple (i.e., non-specific, general purpose assets); and economic agents have the same power over production factors. Information transparency makes it possible to trust anonymous agents, so that the costs of a rapid negotiation can be recovered more frequently (Williamson 1985).

However, those were not Peru's market characteristics in the 1950s and 1960s. Therefore, market governance was more suitable. The market governance mechanism allows lowering governance costs in the fishmeal industry. Fishmeal is a commodity traded in a primary, general-use sector. Its production process is not sophisticated and does not require specialized human capital. Moreover, its elementary activities (fishing and processing) involve simple, easily imitable technologies, which can hardly become differential factors. The production process does not involve specific assets, but rather a general-purpose asset (fish), accessible to other buyers via the market; i.e., it is not a differentiated product. It was not a Porter context: economies of scale were not required to diminish costs; and, at least initially, it was not necessary to implement production according to vertical integration criteria and under the supervision of a higher layer of authority, as in an integrated company. That was Banchero's 
choice, but it could have been implemented by any other entrepreneur under the same conditions. As evidence of this strategy, Banchero purchased an out-of-operation canning plant in association with two partners, Mannucci and de la Riva. Later, in the face of difficulties with the price of fish, he invested in fishing vessels (bolicheras): "The conflict within the fishing bourgeoisie between vessel and plant owners revolved around the price of anchoveta catch" (Caravedo 1979, 52). Banchero later hired engineers with experience in the mining industry (Roemer 1970), who did not required further technological specialization; and former engineering classmates, with whom he maintained a trust relationship that he used for the benefit of the company. He invested in his first fishmeal plant in partnership with, among others, a US subsidiary firm. Banchero responded to price falls by purchasing partners' shares, in case markets took time to recover. He also shared piece rate payments to fishermen (who initially did not pay social security contributions) with other shipbuilders (Caravedo 1979, 53). He only implemented vertical integration when it was essential for sustaining production. Moreover, he played a leading role in the creation of Peru's Fishing Consortium, a powerful lobby with the ability to pressure Peru's Congress and Government, thus creating a monopolization/denationalization trend in the fishing industry (Caravedo 1979, 63, 64, 70).

We maintain that, in implementing competition under market governance, Banchero developed particular personal skills, involving social capital and its embeddedness in Peruvian society, which allowed him to diminish governance costs more than any other company. This happened in a context where agents were not loyal and information was not accessible; on the contrary, Peru's social and cultural environment in the 1950s and 1960s was marked by opportunism instead of loyalty, limited rationality, and scarce information on market agents. Banchero, as an entrepreneur, developed distinctive resources not confined to his professional, scientific, 
technological, and academic knowledge. He developed inventive, innovative, and integrative skills (acquired from close friends, most of them of recent immigrant descent like him, and from fellow engineers with experience in the industry), which materialized in the exploitation of tacit knowledge and social capital. Banchero came through as trustworthy and able to articulate stakeholders' interests in a fundamentally unstable political and economic context under an essentially corrupt National State (Quiroz 2013). He was a dealer with the capacity to negotiate prices more efficiently and obtain the best possible information in a society characterized by imperfect economic rationality and segmented social relations (which did not form a system as such). Banchero's performance promoted a value chain that was key to the growth of his business. This strategy fostered confidence among Banchero's employees, partners, and clients, who willingly shared the risks involved in his ventures. Such strategy was difficult to replicate, as it required a skillful management of both tangible and intangible assets (Barney 1991). It involved skills that were not learned theoretically or conceptually, but rather emerged from acting experience. This kind of learning is best encapsulated by the phrase: "We can know more than we can tell'". This is key to winning stakeholders' trust and inducing them to follow the leader. It is an ineffable element (Polanyi 1966, 4; Spender 1993; Nonaka, Reinmoeller and Senoo 1999).

Such entrepreneurs push themselves to absorb diverse forms of knowledge and venture into social contexts that are not fully integrated, but rather compartmentalized, involving diverse participants like fishermen, sellers, businessmen, engineers, technicians, and exporters. All those who played an important role in Banchero's life-his immigrant family, his former engineering classmates, the fishermen who worked for him, the entrepreneurs he did business with-provided him with tacit knowledge, from the most basic experiences to the most 
sophisticated technical practices, which he used to serve his vision. Social capital is formed by trust-based networks of connections aimed at performing transactions that can be beneficial to all parties (Nahapiet and Ghoshal 1998).

The literature on social capital (Nahapiet and Ghoshal 1998) indicates that social capital facilitates the creation of new intellectual capital through knowledge exchange and combination; that organizations, by sharing and transmitting knowledge, generate organizational advantage, where social capital sitting in social networks is a valuable element; and that access to such networks provides privileged information and opportunities, which other organizations cannot access, thereby creating comparatively higher growth in certain organizations. The evidence from Banchero's case shows that social capital does not materialize just by being there.

The literature based on Granovetter (1992) considers structural and relational embeddedness; and distinguishes between the properties of a relations network and the personal relations within a given history or biography. Relational embeddedness is important, as it brings individuals closer to their capacity of action or choice. This is relevant for understanding that other individuals with the same willingness to do business may start from the same structural social conditions; but only a particular individual attitude and strategic disposition to exploit social relations triggers certain responses from eventual and unsuspected stakeholders: relatives, former engineering classmates, close friends, fishermen, etc., as evidenced by Banchero's biography.

Building on Granovetter's findings, Nahapiet and Ghoshal (1998) state that intellectual capital emerges from certain development conditions for social capital. In this regard, organizations 
contribute to generating knowledge, which provides them with organizational advantage. Additionally, based on Polanyi (1966), Spender (1996), and other authors, it is possible to distinguish between tacit/explicit and individual/social knowledge. This classification admits combinations: individual explicit, individual tacit, social explicit, and social tacit knowledge. The first one can be stored and accessed specifically. The second one is of an automatic, rather practical nature. The third one is objectified, shared, collective, and laid out in texts and manuals. The last one (social tacit knowledge) becomes manifest in institutional practice and emerges from inter-relations that cannot be replicated by other institutions like a recipe. It assumes an embeddedness into the daily practice of an organization's members. Entrepreneurs are coordinators of interests: they learn spontaneously-not explicitly, scientifically, or academically - to discover opportunities and identify market participants willing to sell or purchase. They develop a "know how" rather than a "know what". They learn by doing and focus on action rather than objectives. They use a "knowing capability" to exploit opportunities by articulating interests. How do they transform this ability into a factor that makes extraordinary growth possible?

The literature on social capital suggests that intellectual capital can be more valuable than material assets (e.g., land, money, or equipment). Banchero's biography shows how this capacity translated into business growth by reducing transaction costs between stakeholders; and, more generally, articulating stakeholders who previously were not linked by a common interest. In this context, carrying out transactions implies mobilizing resources in a timely manner. This in turn implies identifying a community of interest within the organization; and between the organization, on one hand, and labor suppliers and buyers, on the other hand; as well as articulating supply of, and demand for, increasing output volumes. In the process, 
transactions must be carried out in a timely manner between fish catching, processing, and exporting. Two critical elements in the production chain are catch volume and foreign demand for fishmeal.

Banchero's supply grew steadily and needed to be absorbed by the market. As a result of his ability to persuade fishermen to produce more, supply always exceeded demand. Spanish fishmeal magnate Joaquín Peña suggested to reach out to new buyers in Eastern Europe (Thorndike 2019, 170). Table 2 shows that Banchero succeeded in boosting Peru's share of exports to Eastern Europe from $9.7 \%$ in 1958 to $23.1 \%$ in 1967 . This was possible to a great extent thanks to Banchero's push and initiative.

TABLE 2. Fishmeal exports to Eastern Europe

\begin{tabular}{|l|c|c|c|c|}
\hline \multirow{2}{*}{} & \multicolumn{4}{|c|}{ Fishmeal exports to Eastern Europe (\% from total) } \\
\cline { 2 - 5 } & $\mathbf{1 9 5 8}$ & $\mathbf{1 9 6 3}$ & $\mathbf{1 9 6 6}$ & $\mathbf{1 9 6 7}$ trim I \\
\hline German Democratic Republic & 0 & 3,7 & 9,1 & 5,7 \\
\hline Bulgaria & 0 & 0,2 & 1,3 & 0,9 \\
\hline Chezchoslovakia & 0 & 0,7 & 1,7 & 4,3 \\
\hline Hungary & 0 & 1,6 & 1 & 2,0 \\
\hline Poland & 0 & 0,8 & 4,4 & 5,1 \\
\hline Yugoslavia & 0 & 2,7 & 3,8 & 4,3 \\
\hline Romania & 0 & 0 & 0,8 & 0,9 \\
\hline Total & 0 & 9,7 & 22,1 & 23,1 \\
\hline
\end{tabular}

Source: Pesca journal.

This talent for articulating interests was based on his fiduciary capacity; i.e., offering wealth originated by products or services he did not possess or had not yet created. Therefore, a second feature of this tacit knowledge or know-how, when translating into growth, is its capacity for fiduciary generation; i.e., by creating trust among stakeholders with differing interests, Banchero was able to persuade them to enroll in his company or grant him unsecured loans. 
This embeddedness of the company's rationality into its network of relations via negotiation was not confined to finding common ground between conflicting interests within the industrial sector alone. It extended into the ability to develop broad and structural political connections at the government level and to exert lobbying pressure on Congress and the Executive. Very rapidly Banchero took the leadership of what Caravedo (1979) called the "fisheries faction", which blocked the enactment of legislation against predation and the creation of environmental imbalances, among other benefits to the industry, a subject that was extensively discussed internationally at least since the 1940s (Cushman 2018). The "fisheries faction" was relatively successful during the Prado administration (1956-1962); but obtained considerable gains in 1963-1968 by using influence to persuade the APRA-UNO congressional alliance to support initiatives opposed by President Fernando Belaúnde, leader of the Acción Popular party:

The Belaúnde administration succumbed to pressures not only from social forces, which did not use congressional channels, but also from his own cabinet and Congress, where the APRA-UNO coalition held a majority (Caravedo 1979, 67).

As a result, Law 15048 of 1964 favored domestic industry through tax cuts and preferential loans; and Law 16694 of 1967 promoted the creation of a domestic monopoly, led by Banchero, in partnership with foreign capitals, which drove small and medium producers out of the market:

Within the SNP [National Fisheries Association], Luis Banchero represented monopolistic interests. He had political connections with certain sectors of the Acción Popular, Democracia Cristiana, and APRA parties (Caravedo 1979, 73).

This is confirmed by Clarke:

Within the fisheries industry [...] APRA congressmen and senators participated in the "fisheries cell", which successfully supported the interests of the industry in the complex congressional climate during the Belaúnde administration (Clarke 2018, 361-362). 
Banchero's spontaneous individual tacit knowledge articulated the individual tacit knowledge of fishermen (acquired from their work at sea) and salesmen; the individual explicit knowledge of technicians and engineers; and the social knowledge, both tacit (i.e., a sense of belonging and trust) and explicit (i.e., the contribution of engineers and managers in terms of economic rationality and market awareness). Paternalism involves an intense labor relationship whereby employers seek mechanisms to condition their employees' decisions and autonomy. This leadership style may take three forms: benevolent (employers have a genuine interest in their employees and the latter develop a sense of loyalty); moral (employees accept a greater degree of authority from employers); and authoritarian (employees accept absolute and unquestionable authority from employers). Presumably labor relations improve, and organizational gains emerge, within the first two categories(Mussolino and Calabró 2014). The evidence suggests that Banchero's leadership style qualifies as benevolent paternalism (Thorndike 1980; Rossi 2011). Significantly, within and outside the organization, Banchero was known as the Man (Thorndike 1980, 136).

At the same time, Banchero's paternalism did not exclude extracting benefits from labor to serve the interests of medium- and large-scale producers (in partnership with foreign monopolistic capital); or participating in ocean predation: early on, Banchero established an alliance with APRA unions, known as the "mafia" (Clarke 2018, 362). Building on findings by Sulmont and Flores Galindo, Caravedo states the following: "The mafia that prevailed over all others in 1960-65 was the one run by Banchero ". (Flores and Sulmont 1972, 101-102; Caravedo 1979, 58). In literature, José María Arguedas's "El zorro de arriba y el zorro de abajo" (Arguedas 1983) provides a critical and harsh depiction of those times. 
Banchero had an ineffable empirical knowledge of the behavioral patterns of diverse stakeholders. His talent for developing empathy across a range of social, cultural, organizational, labor, and professional environments proved instrumental in creating commitment towards the organization. Notably, according to Denis Sulmont and Alberto Flores Galindo, Banchero succeeded in establishing a seemingly horizontal relationship with fishing workers due to his ability to adapt the human resources practices of his companies to the mentality of his employees, thereby promoting camaraderie and esprit de corps. An important element in Peruvian fishermen's mindset is an admiration for the "self-made man", in addition to skill and cleverness. This close employer/employee connection is exemplified by initiatives like rewarding a number of workers by paying for their attendance to the 1970 Soccer World Cup; or finding time to join them for drinks (Flores and Sulmont 1972; Rossi 2011, 132-134). As the son of Italian immigrants, Banchero did not inherit authoritarian legacies from Peru's colonial times. Flores Galindo suggests that the Spaniards' vertical dominion over the population of native and African descent was preserved in Peru's estates when republican rule weakened the political power of the clergy and provincial officials. With the oligarchy as the new political, economic, and social group in power, vertical authority gradually passed on to factories as urban centers became more industrialized; and the landowner/peasant paradigm morphed into an owner/worker relationship marked by social distancing (Flores 2001, 184).

This tacit knowledge embedded in his personality and initiatives also translated into technological innovation and corporate bureaucratic streamlining: former Tacna schoolmates and Trujillo college classmates, Trujillo acquaintances, Chimbote fishermen (with whom he partied and drank beer), and immigrant partners combined and articulated their diverse and complementary knowledge within OYSSA. The organization reinforced previously weak 
linkages. Over a short period (1955-1964) technological innovation accelerated, spurred by the constantly growing world demand for fishmeal, under Banchero's bold leadership and increasingly sophisticated managerial model. The Banchero Group was among the first to adopt such innovations. Banchero's fiduciary reputation extended beyond the organization and the stakeholder circle, to the point of being considered presidential material in his time and gaining iconic status among the Peruvian population to this day (Hernández 2020).

\section{Concluding Remarks}

In the 1960s, Peru became the world's major fishmeal exporter due to a combination of historical, economic, and political factors. Like other Peruvian commodities (e.g., guano and nitrate in the 19th century, and currently mining), fishmeal production surged in a favorable international context. However, these economic factors do not explain how Luis Banchero, a Peruvian entrepreneur with incipient knowledge of industrial fishing and scarce initial capital, became Peru's major fishmeal exporter, even surpassing foreign-financed companies. This article explains the strategy and capacities that Banchero developed to achieve such unprecedented success.

Banchero used a market governance structure, which is a rational choice considering Peru's conditions in the 1950s and 1960s: opportunism, uncertainty, scarce economic rationality, and absence of reliable information. At the same time, this alternative was perfectly imitable by all other competitors. In response, Banchero developed certain capacities that exceeded explicit economic knowledge accessible through institutional channels; and exploited elements of his own intellect and that of eventual stakeholders, especially tacit social knowledge within his organization, thereby generating organizational advantage and fostering trust and social capital 


\section{Journal of Evolutionary Studies in Business}

for the benefit of his companies. He also led lobbies and interest groups (e.g., the Fishing Consortium) connected with Peru's Congress and Government, which promoted legislation for the benefit of the Consortium in general and his companies in particular. 


\section{References}

Arguedas, José María. 1983. El zorro de arriba y el zorro de abajo. Tomo V de Obras completas. Lima: Editorial Horizonte.

Abramovich, Jaysuño. 1973. La industria pesquera en el Perú: Génesis, apogeo y crisis. Lima: Universidad Nacional Federico Villarreal.

Barney, Jay. 1991. "Firm resources and sustained competitive advantage". Journal of Management 17(1): 97-98. doi: 10.1177\%2F014920639101700108.

Brundenius, Claes. 1973. "The rise and fall of the Peruvian fishmeal industry." Instant Research on Peace and Violence 3: 149-58.

Caravedo Molinari, Baltazar. 1979. Estado, pesca y burguesía 1939-1973. Lima: Centro de Proyección Cristiana.

Clarke, Nathan. 2018. "La revolución peruana y los trabajadores en Chimbote, 1968-1973." In La revolución peculiar: repensando el gobierno militar de Velasco, edited by Carlos Aguirre, and Paulo Drinot, 353-88. Lima: Instituto de Estudios Peruanos.

Cushman, Gregory. 2018. Los señores del guano. Una historia ecológica global del Pacífico. Lima: Institutos de Estudios Peruanos.

Flores Galindo, Alberto and Denis Sulmont. 1972. El movimiento obrero en la industria pesquera: el caso de Chimbote. Lima: Programa Académico de Ciencias Sociales de la Pontificia Universidad Católica del Perú; Taller Urbano Industrial.

Flores Galindo, Alberto. 2001. Los rostros de la plebe. Barcelona: Crítica.

Granovetter, Mark S. 1992. "Problems of explanation in economic sociology." In Networks and organizations: Structure, form and action, edited by Nitin Nohria and Robert G. Eccles, 25-56. Boston: Harvard Business School Press.

Hernández Lefranc, Harold. 2020. "El caso Banchero, de Guillermo Thorndike: fuente impresa que explica el culto a Luis Banchero Rossi, santo secular, en Lima.” Anthropologica XXXVIII (44): 297-318. doi: 10.18800/anthropologica.202001.012.

Malpica, Carlos. 1992. El poder económico en el Perú: Empresas de capital extranjero. Lima: Perugraph.

Mussolino, Donata, and Andrea Calabrò. 2014. "Paternalistic leadership in family firms. Types and implications for intergenerational succession.” Journal of Family Business Strategy 5: 197-210. doi: $10.1016 /$ j.jfbs.2013.09.003. 
Nahapiet, Janine and Sumantra Ghoshal. 1998. "Social capital, intellectual capital, and the organizational advantage." Academy of Management Review 23: 242-66. doi: doi.org/10.2307/259373.

Nonaka, Ikujiro, Patrick Reinmoeller, and Dai Senoo. 1999. 'El 'ART' del conocimiento: sistemas para rentabilizar el conocimiento de mercado”. Harvard Deusto Business Review 92: 6-21.

Polanyi, Michael. 1966. The Tacit Dimension. Chicago: The University of Chicago Press.

Porter, Michael. 1991. La ventaja competitiva de las naciones. Buenos Aires: Vergara.

Portocarrero, Felipe. 1992. Compendio estadístico del Perú 1900-1990. Lima: Universidad del Pacífico.

Quiroz, Alfonso. 2013. Historia de la corrupción en el Perú. Lima: Instituto de Estudios Peruanos.

Roemer, Michael 1970. Fishing for growth Export-led development in Perú 1950-1967. Cambridge: Harvard University press.

Rossi, Benito. 2011. La pesca en el Perú. Remembranzas de una vida en la industria 1955-2005. Lima: QG Editores.

Seminario, Bruno. 2015. El desarrollo de la economía peruana en la era Moderna. Precios, población, demanda y producción desde 1700. Lima: Universidad del Pacífico.

Spender, J. C. 1993. "Competitive advantage from tacit knowledge? Unpacking the concept and its strategic implications." Academy of Management Best Papers Proceedings 1: 37-41. doi: 10.5465/ambpp.1993.10315222.

Spender, J.C. 1996. "Making knowledge the basis of a dynamic theory of the firm." Strategic Management Journal 17 (S2): 45-62. doi: 10.1002/smj.4250171106.

Thorndike, Guillermo. 1980. El Caso Banchero. Lima: Mosca azul.

Thorndike, Guillermo. 2019. El Caso Banchero. Lima: Planeta.

Thorp, Rosemary, and Geoffrey Bertram. 2013. Perú 1890-1977: Crecimiento y políticas en una economía abierta. Lima: Universidad del Pacífico.

Vásquez, Enrique. 2000. Estrategias del poder. Grupos económicos en el Perú. Lima: Universidad del Pacífico.

Williamson, Oliver. 1985. The economic institutions of capitalism. New York: The Free Press. 


\section{Journal of Evolutionary Studies in Business}

Figure 2.

Banchero's Portfolio

\section{Fish catch}

Fishermen

Patrón

Fishermen

\section{Production}

\section{Fishmeal*}

Pesquera Humboldt

Ferroles

Pesca Mar

Pesquera Argos

Pesquera Trujillo

Productos Alimenticios

Pesquera Paracas

Pesquera San José

\section{Canned fish*}

Cadena Envasadora San Fernando

Compañía Pesquera Florida

Conservas Miramar

Envasadora Miramar

Pesquera industrial Callao

Pesca y Envase Chimbote

Agropesca

Sales
Supliers

Shipyard*

PICSA

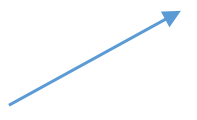

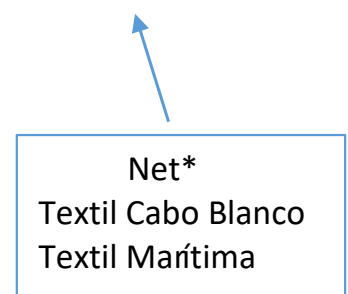

Humboldt*

International

De Hamburgo

\section{Other \\ Empresa Periodística Nacional \\ Productos y Forrajes \\ Food and Feeds \\ Herramientas \\ Seguros Panamericana \\ Club de fútbol Defensor Lima}

Source: Compiled by authors.

This is an Open Access article distributed under the terms of the Creative Commons Attribution-Non-Commercial-No Derivatives License (http://creativecommons.org/licenses/by-nc-nd/4.0/), which permits non-comercial re-use and distribution, provided the original work is properly cited, and is not altered or transformed in any way. 